\title{
Hak Atas Kekayaan Intelektual Dalam Teknologi Informasi dan Komunikasi
}

\author{
Repita Sari \\ 155100064, 785567826 \\ Fakultas Komputer \\ repitasari.student@umitra.ac.id
}

\begin{abstract}
Hak Atas Kekayaan Intelektual (HAKI) ini merupakan padanan dari bahasa Inggris Intellectual Property Right. Kata "intelektual" tercermin bahwa obyek kekayaan intelektual tersebut adalah kecerdasan, daya pikir, atau produk pemikiran manusia (the Creations of the Human Mind) (WIPO, 1988:3).

Hak Kekayaan Intelektual (HAKI) adalah hak eksklusif Yang diberikan suatu peraturan kepada seseorang atau sekelompok orang atas karya ciptanya. Secara sederhana HAKI mencakup Hak Cipta, Hak Paten Dan Hak Merk. Namun jika dilihat lebih rinci HAKI merupakan bagian dari benda (Saidin : 1995), yaitu benda tidak berwujud (benda imateriil).

Hak Atas Kekayaan Intelektual (HAKI) termasuk dalam bagian hak atas benda tak berwujud (seperti Paten, merek, Dan hak cipta). Hak Atas Kekayaan Intelektual sifatnya berwujud, berupa informasi, ilmu pengetahuan, teknologi, seni, sastra, keterampilan Dan sebaginya Yang tidak mempunyai bentuk tertentu
\end{abstract}

Kata Kunci : pengertian HAKI.

\section{A. INTRODUCTION}

Dalam menciptakan suatu kepemilikan, suatu hasil karya yang baru, perlu adanya pendefinisian sifat dan hakikat kepemilikannya. Kekayaan Intelektual (Intelectual Property) merupakan hasil pemikiran dan budidaya 
manusia yang perlu mendapat perlindungan hukum dari pembajakan maupun tindakan ilegal lainnya.

Yang termasuk dalam HAKI :

1. Hak Cipta (Copyright)

2. Merek Dagang (trademarks)

3. Paten (patent)

4. Desain produk Industri (industrial design)

5. Indikasi geografi (geographical indication)

6. Desain tata letak sirkuit tepadu/layout desain (topography of integrated circuits)

7. Perlindungan informasi yang dirahasiakan (protection of undisclosed information)

Bentuk-bentuk ciptaan yang dilindungi oleh UU Hak Cipta:

- Buku, program komputer, pamflet, perwajahan (layout) karya tulis yang diterbitkan, dan semua hasil karya tulis lain.

- Ceramah, kuliah, pidato, dan ciptaan lain yang sejenis dengan itu.

- Alat peraga yang dibuat dengan kepentingan pendidikan dan ilmu pengetahuan

- Lagu atau musik dengan atau tanpa teks.

- Drama atau drama musikal, tari, koreografi, pewayangan dan pantomim.
- Seni rupa dalam segala bentuk seperti seni lukis, gambar, seni ukir, seni kaligrafi, seni pahat, seni pahat, seni patung, kolase dan seni terapan.

- Arsitektur

- Peta

- Seni batik

- Fotografi

- Sinematografi

- Terjemahan, tafsir, saduran, bunga rampai, database, dan karya lain dari hasil pengalihwujudan.

- Buku, CD-ROM, dan tape/kaset adalah bentuk fisik yang mempunyai Paten dan Hak Cipta.

\section{Hak Cipta Perangkat Lunak}

Hak Cipta merupakan hak eksklusif bagi Pencipta atau Pemegang Hak Cipta untuk mengumumkan atau memperbanyak ciptaannya, yang timbul secara otomatis setelah suatu ciptaan dilahirkan tanpa mengurangi pembatasan menurut peraturan perundangundangan yang berlaku. (Undang-Undang Hak Cipta No. 19 tahun 2002 Pasal 2).

Perangkat lunak adalah sekumpulan perintah yang ditulis oleh bahasa pemrograman yang dimengerti oleh komputer sehingga perangkat lunak tersebut mampu menginstruksikan perintah tertentu yang akan dikerjakan oleh komputer. 
Perangkat lunak dan komputer tidak dapat dipisahkan karena komputer akan bekerja apabila ada perangkat lunak yang ditulis oleh seorang pemrograman (programmer). Menciptakan perangkat lunak bukan merupakan pekerjaan yang mudah karena banyak sekali aturan-aturan dan kemampuan intelektual yang dibutuhkan dari seorang analis sistem (system analyst) dan pemrograman. Oleh karena itulah, dengan berlakunya Undang-Undang Hak Cipta, hasil kerja seorang analis sistem dan pemrograman dapat dilindungi.

\section{Undang-Undang Hak Cipta}

Undang-undang yang melindungi hak cipta seseorang adalah Undang-Undang No. 19 Tahun 2002 yang terdiri atas 15 bab dan 78 pasal.

Pasal 2

(1) Hak Cipta merupakan hak eksklusif bagi Pencipta atau Pemegang Hak Cipta untuk mengumumkan atau memperbanyak ciptaannya, yang timbul secara otomatis setelah suatu ciptaan dilahirkan tanpa mengurangi pembatasan menurut peraturan perundang-undangan yang berlaku.

Pasal 49
(1) Pelaku memiliki hak eksklusif untuk memberikan izin atau melarang pihak lain yang tanpa persetujuannya membuat, memperbanyak, atau menyiarkan rekaman suara dan / atau gambar petunjukannya

(2) Produsen rekaman suara memiliki hak ekskulisif untuk memberikan izin atau melarang pihak lain yang tanpa persetujuannya memperbanyak dan / atau menyewakan karya rekaman suara atau rekaman bunyi.

Pasal 72

(1) Barangsiapa dengan sengaja dan tanpa hak melakukan perbuatan sebagaimana dimaksud dalam pasal 2 ayat (1) atau pasal 49 ayat (1) dan ayat (2) dipidana dengan pidana penjara masingmasing paling singkat 1 (satu) bulan dan / atau denda paling sedikit Rp. 1.000.000,00 (satu juta rupiah), atau pidana penjara paling lama 7 (tujuh) tahun dan / atau denda paling banyak Rp. 5.000.000.000,00 (lima miliar rupiah)

(2) Barang siapa dengan sengaja, menyiarkan, ,memamerkan, mengedarkan atau menjual kepada umum suatu ciptaan atau barang hasil pelanggaran Hak Cipta atau Hak Terkait sebagaimana dimaksud pada ayat (1) dipidana dengan pidanan penjara paling lama 5 (lima) tahun dan / atau denda paling banyak Rp. 500.000.000,00 (lima juta rupiah). 
(3) Barangsiapa dengan sengaja dan tanpa hak memperbanyak penggunaan untuk kepentingan komersial suatu Program Komputer dipidana dengan pidana penjara paling lama 5 (lima) tahun dan / atau denda paling banyak Rp. 5000.000.000,00

\section{B. CONTENT}

Hak Atas Kekayaan Intelektual (HAKI) ini merupakan padanan dari bahasa Inggris Intellectual Property Right. Kata "intelektual" tercermin bahwa obyek kekayaan intelektual tersebut adalah kecerdasan, daya pikir, atau produk pemikiran manusia (the Creations of the Human Mind) (WIPO, 1988:3).

Hak Kekayaan Intelektual (HAKI) adalah hak eksklusif Yang diberikan suatu peraturan kepada seseorang atau sekelompok orang atas karya ciptanya. Secara sederhana HAKI mencakup Hak Cipta, Hak Paten Dan Hak Merk. Namun jika dilihat lebih rinci HAKI merupakan bagian dari benda (Saidin : 1995), yaitu benda tidak berwujud (benda imateriil).

Hak Atas Kekayaan Intelektual (HAKI) termasuk dalam bagian hak atas benda tak berwujud (seperti Paten, merek, Dan hak cipta). Hak Atas Kekayaan Intelektual sifatnya berwujud, berupa informasi, ilmu pengetahuan, teknologi, seni, sastra, keterampilan Dan sebaginya Yang tidak mempunyai bentuk tertentu Secara umum Hak Kekayaan Intelektual dapat terbagi dalam dua kategori yaitu: 1. Hak Cipta. 2. Hak Kekayaan Industri, meliputi:
a.
Paten
b. Merek
c. Desain Industri
d. Rahasia Dagang

1. Hak

Cipta

Hak Cipta adalah hak khusus bagi pencipta untuk mengumumkan atau memperbanyak ciptaannya. Termasuk ciptaan yang dilindungi adalah ciptaan dalam bidang ilmu pengetahuan, sastra dan seni. Berdasarkan Undang-Undang Nomor 19 Tahun 2002 Tentang

Hak Cipta

Hak Cipta adalah hak eksklusif bagi Pencipta atau penerima hak untuk mengumumkan atau memperbanyak Ciptaannya atau memberikan izin untuk itu dengan tidak mengurangi pembatasan-pembatasan menurut peraturan perundangundangan yang berlaku.(Pasal 1 ayat 1) Hak cipta diberikan terhadap ciptaan dalam ruang lingkup bidang ilmu pengetahuan, kesenian, dan kesusasteraan. Hak cipta hanya diberikan secara eksklusif kepada pencipta, yaitu "seorang atau beberapa orang secara bersama-sama yang atas 
inspirasinya lahir suatu ciptaan berdasarkan pikiran, imajinasi, kecekatan, keterampilan atau keahlian yang dituangkan dalam bentuk yang khas dan bersifat pribadi”.

Subyek Hak Cipta Pencipta

seseorang atau beberapa orang secara bersama-sama yang atas inspirasinya lahir suatu ciptaan berdasarkan kemampuan pikiran, imajinasi, kecekatan, keterampilan atau keahlian yang dituangkan dalam bentuk yang khas dan bersifat pribadi. Pemegang Hak Cipta Pencipta sebagai Pemilik Hak Cipta atau orang lain yang menerima lebih lanjut hak dari orang tersebut diatas.

$\begin{array}{llr}\begin{array}{l}\text { Obyek Hak } \\ \text { Ciptaan }\end{array} & \text { Cipta } \\ \text { yaitu hasil } & \text { setiap } & \text { karya }\end{array}$ Pencipta dalam bentuk yang khas dan menunjukkan keasliannya dalam lapangan ilmu pengetahuan, seni dan sastra. Ciptaan yang dilindungi adalah Ciptaan dalam bidang ilmu pengetahuan, seni dan sastra.

Undang-Undang yang mengatur Hak Cipta

- UU Nomor 19 Tahun 2002 tentang Hak Cipta

- UU Nomor 6 Tahun 1982 tentang Hak Cipta (Lembaran Negara RI Tahun 1982 Nomor 15)
- $\quad$ UU Nomor 7 Tahun 1987 tentang Perubahan atas UU Nomor 6 Tahun 1982 tentang Hak Cipta (Lembaran Negara RI Tahun 1987 Nomor 42)

- UU Nomor 12 Tahun 1997 tentang Perubahan atas UU Nomor 6 Tahun 1982 sebagaimana telah diubah dengan UU Nomor 7 Tahun 1987 (Lembaran Negara RI Tahun 1997 Nomor 29)

2. Hak Paten Berdasarkan Undang-Undang Nomor 14 Tahun 2001: Paten adalah hak eksklusif yang diberikan oleh Negara kepada Inventor atas hasil invensinya di bidang teknologi, yang untuk selama waktu tertentu melaksanakan sendiri invensinya tersebut atau memberikan persetujuannya kepada pihak lain untuk melaksanakannya (Pasal 1 Ayat 1). Hak khusus yang diberikan negara kepada penemu atas hasil penemuannya di bidang teknologi, untuk selama waktu tertentu melaksanakan sendiri penemuannya tersebut atau memberikan persetujuan kepada orang lain untuk melaksanakannya (Pasal 1 Undang-undang Paten). Paten diberikan dalam ruang lingkup bidang teknologi, yaitu ilmu pengetahuan yang diterapkan dalam proses industri. Di samping paten, dikenal pula paten sederhana (utility models) yang hampir 
sama dengan paten, tetapi memiliki syarat-syarat perlindungan yang lebih sederhana. Paten dan paten sederhana di Indonesia diatur dalam Undang-Undang Paten (UUP).

Paten hanya diberikan negara kepada penemu yang telah menemukan suatu penemuan (baru) di bidang teknologi. Yang dimaksud dengan penemuan adalah kegiatan pemecahan masalah tertentu di bidang teknologi yang berupa :

a. proses;

b. hasil produksi;

c. penyempurnaan dan pengembangan proses; d. penyempurnaan dan pengembangan hasil produksi;

Undang-Undang yang mengatur Hak Paten

- $\quad$ UU Nomor 6 Tahun 1989 tentang Paten (Lembaran Negara RI Tahun 1989 Nomor 39)

- $\quad$ UU Nomor 13 Tahun 1997 tentang Perubahan UU Nomor 6 Tahun 1989 tentang Paten (Lembaran Negara RI Tahun 1997 Nomor 30)

- UU Nomor 14 Tahun 2001 tentang Paten (Lembaran Negara RI Tahun 2001 Nomor 109)

\section{Merek}

Merek dagang adalah merek yang digunakan pada barang yang diperdagangkan oleh seseorang atau beberapa orang secara bersama-sama atau badan hukum untuk membedakan dengan barangbarang sejenis lainnya. Merek jasa yaitu merek yang digunakan pada jasa yang diperdagangkan oleh seseorang atau beberapa orang secara bersama-sama atau badan hukum untuk membedakan dengan jasa-jasa sejenis lainnya.

Merek kolektif adalah merek yang digunakan pada barang atau jasa dengan karakteristik yang sama yang diperdagangkan oleh beberapa orang atau badan hukum secara bersama-sama untuk membedakan dengan barang atau jasa sejenis lainnya. Hak atas merek adalah hak khusus yang diberikan negara kepada pemilik merek yang terdaftar dalam Daftar Umum Merek untuk jangka waktu tertentu, menggunakan sendiri merek tersebut atau memberi izin kepada seseorang atau beberapa orang secara bersama-sama atau badan hukum untuk menggunakannya.

Undang-Undang yang mengatur Merk

- $\quad$ UU Nomor 19 Tahun 1992 tentang Merek (Lembaran Negara RI Tahun 1992 Nomor 81)

- UU Nomor 14 Tahun 1997 tentang Perubahan UU Nomor 19 Tahun 1992 tentang Merek (Lembaran 
Negara RI Tahun 1997

Nomor 31)

- UU Nomor 15 Tahun 2001 tentang Merek (Lembaran Negara RI Tahun 2001 Nomor 110)

\section{Desain Industri} (Berdasarkan Undang-Undang Nomor 31 Tahun 2000 Tentang Desain Industri) : Desain Industri adalah suatu kreasi tentang bentuk, konfigurasi, atau komposisi garis atau warna, atau garis dan warna, atau gabungan daripadanya yang berbentuk tiga dimensi atau dua dimensi yang memberikan kesan estetis dan dapat diwujudkan dalam pola tiga dimensi atau dua dimensi serta dapat dipakai untuk menghasilkan suatu produk, barang, komoditas industri, atau kerajinan tangan. (Pasal 1 Ayat 1)

\section{Rahasia Dagang} (Menurut Undang-Undang Nomor 30 Tahun 2000 Tentang Rahasia Dagang) : Rahasia Dagang adalah informasi yang tidak diketahui oleh umum di bidang teknologi dan/atau bisnis, mempunyai nilai ekonomi karena berguna dalam kegiatan usaha, dan dijaga kerahasiaannya oleh pemilik Rahasia Dagang.

\section{CONCLUSION}

Dalam menciptakan suatu kepemilikan, suatu hasil karya yang baru, perlu adanya pendefinisian sifat dan hakikat kepemilikannya. Kekayaan Intelektual (Intelectual Property) merupakan hasil pemikiran dan budidaya manusia yang perlu mendapat perlindungan hukum dari pembajakan maupun tindakan ilegal lainnya.

Yang termasuk dalam HAKI :

8. Hak Cipta (Copyright)

9. Merek

Dagang (trademarks)

10. Paten (patent)

11. Desain produk Industri (industrial design)

12. Indikasi geografi (geographical indication)

13. Desain tata letak sirkuit tepadu/layout desain (topography of integrated circuits)

14. Perlindungan informasi yang dirahasiakan (protection of undisclosed information)

Bentuk-bentuk ciptaan yang dilindungi oleh UU Hak Cipta:

- Buku, program komputer, pamflet, perwajahan (layout) karya tulis yang diterbitkan , dan semua hasil karya tulis lain.

- Ceramah, kuliah, pidato, dan ciptaan lain yang sejenis dengan itu.

- Alat peraga yang dibuat dengan kepentingan pendidikan dan ilmu pengetahuan 
- Lagu atau musik dengan atau tanpa teks.

- Drama atau drama musikal, tari, koreografi, pewayangan dan pantomim.

- Seni rupa dalam segala bentuk seperti seni lukis, gambar, seni ukir, seni kaligrafi, seni pahat, seni pahat, seni patung, kolase dan seni terapan.

- Arsitektur

- Peta

- Seni batik

- Fotografi

- Sinematografi

- Terjemahan, tafsir, saduran, bunga rampai, database, dan karya lain dari hasil pengalihwujudan.

- Buku, CD-ROM, dan tape/kaset adalah bentuk fisik yang mempunyai Paten dan Hak Cipta.

\section{Hak Cipta Perangkat Lunak}

Hak Cipta merupakan hak eksklusif bagi Pencipta atau Pemegang Hak Cipta untuk mengumumkan atau memperbanyak ciptaannya, yang timbul secara otomatis setelah suatu ciptaan dilahirkan tanpa mengurangi pembatasan menurut peraturan perundangundangan yang berlaku. (Undang-Undang Hak Cipta No. 19 tahun 2002 Pasal 2).

Perangkat lunak adalah sekumpulan perintah yang ditulis oleh bahasa pemrograman yang dimengerti oleh komputer sehingga perangkat lunak tersebut mampu menginstruksikan perintah tertentu yang akan dikerjakan oleh komputer.

Perangkat lunak dan komputer tidak dapat dipisahkan karena komputer akan bekerja apabila ada perangkat lunak yang ditulis oleh seorang pemrograman (programmer). Menciptakan perangkat lunak bukan merupakan pekerjaan yang mudah karena banyak sekali aturan-aturan dan kemampuan intelektual yang dibutuhkan dari seorang analis sistem (system analyst) dan pemrograman. Oleh karena itulah, dengan berlakunya Undang-Undang Hak Cipta, hasil kerja seorang analis sistem dan pemrograman dapat dilindungi.

\section{DISCUSSION}

Secara institusional, pada saat ini telah ada Direktorat Jendral Hak Kekayaan Intelektual yang tugas dan fungsi utamanya adalah menyelenggarakan administrasi hak cipta paten, merek, desain industri, dan desain tata letak sirkuit terpadu. Direktorat Jenderal Hak Kekayaan Intelektual (semula disebut Direktorat Jenderal Hak Cipta, Paten dan Merek) dibentuk pada thaun 1998. Direktorat Jendral Hak Kekayaan Intelektual yang baik sebagaimana yang diharapkan 
oleh masyarakat, baik yang berasal dari dunia industri dan perdagangan, maupun dari institusi yang bergerak di bidang penelitian dan pengembangan.

Sejauh ini pegawai di lingkungan Direktorat Jenderal Hak Kekayaan Intelektual berjumlah 450 orang. Dibandingkan dengan yang ada di beberapa negara yang telah maju. Direktorat Jendral HaKI merupakan institusi yang relatif masih muda/naru. Oleh sebab itu, dapat dimaklumi seandainya dalam pelaksanaan tugasnya, masih dijumpai berbagai macam kendala. Walaupun demikian, melalui berbagai program pelatihan yang intensif telah ada beberapa staf yang memiliki pengetahuan yang cukup memadai guna mendukung peningkatan sistem hak kekayaan intlektual sebagaimana diharapkan

Perlu pula kiranya dikemukakan bahwa dalam rangka lebih meningkatkan pelayanan dan kemudahan bagi masyarakat, sejak januari 2000, pengajuan permohonan hak kekayaan intelektual dapat dilakukan di Kantor-kantor Wilayah Departemen Kehakiman dan Hak Asasi Manusia

Selanjutnya, Kantor-kantor Wilayah akan menyampaikan permohonan tersebut kepada Direktorat Jenderal HaKI untuk diproses ebih lanjut. Di samping itu, pada saat ini, dengan bantuan World Bank sedang dilaksanakan penyempurnaan sistem otomasi di Direktorat Jenderal HaKI yang diharapkan dapat lebih menunjang proses administrasi dimaksud. Tidak sebagaimana bidang kekayaan intelektual lain yang administrasinya dikelola oleh Direktorat Jenderal HaKI, bidang varietas tanaman ditangani oleh Departemen Pertanian

\section{E. REFERENCE}

[1] O. M. Febriani and A. S. Putra, "Sistem Informasi Monitoring Inventori Barang Pada Balai Riset Standardisasi Industri Bandar Lampung," J. Inform., vol. 13, no. 1, pp. 90-98, 2014.

[2] A. S. Putra, "Paperplain: Execution Fundamental Create Application With Borland Delphi 7.0 University Of Mitra Indonesia," 2018.

[3] A. S. Putra, "2018 Artikel Struktur Data, Audit Dan Jaringan Komputer," 2018.

[4] A. S. Putra, "ALIAS MANAGER USED IN DATABASE DESKTOP STUDI CASE DB DEMOS."

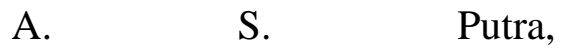
"COMPREHENSIVE SET OF PROFESSIONAL FOR DISTRIBUTE COMPUTING."

[6] A. S. Putra, "DATA ORIENTED RECOGNITION 
IN BORLAND DELPHI 7.0."

[7] A. S. Putra, "EMBARCADERO DELPHI XE 2 IN GPUPOWERED FIREMONKEY APPLICATION."

[8] A. S. Putra, "HAK ATAS KEKAYAAN INTELEKTUAL DALAM DUNIA TEKNOLOGY BERBASIS REVOLUSI INDUSTRI 4.0."

[9] A. S. Putra, "IMPLEMENTASI PERATURAN

PERUNDANGAN UU. NO 31

TAHUN 2000 TENTANG DESAIN INDUSTRI BERBASIS INFORMATION TECHNOLOGY."

[10] A. S. Putra, "IMPLEMENTATION OF PARADOX DBASE."

[11] A. S. Putra, "IMPLEMENTATION OF TRADE SECRET CASE STUDY SAMSUNG MOBILE PHONE."

[12] A. S. Putra, "IMPLEMENTATION

PATENT FOR APPLICATION WEB BASED CASE STUDI WWW. PUBLIKLAMPUNG. COM."

[13] A. S. Putra, "IMPLEMENTATION SYSTEM FIRST TO INVENT IN DIGITALLY INDUSTRY."

[14] A. S. Putra, "MANUAL REPORT \& INTEGRATED DEVELOPMENT

ENVIRONMENT BORLAND DELPHI 7.0."

[15] A. S. Putra, "PATENT AS RELEVAN SUPPORT RESEARCH."

[16] A. S. Putra, "PATENT FOR RESEARCH STUDY CASE
OF APPLE. Inc."

[17] A. S. Putra, "PATENT PROTECTION FOR APPLICATION INVENT."

[18] A. S. Putra, "QUICK REPORT IN PROGRAMMING."

[19] A. S. Putra, "REVIEW CIRCUIT LAYOUT COMPONENT

REQUIREMENT ON ASUS NOTEBOOK."

[20] A. S. Putra, "REVIEW TRADEMARK PATENT FOR INDUSTRIAL TECHNOLOGY BASED 4.0."

[21] A. S. Putra, "TOOLBAR COMPONENT PALLETTE IN OBJECT ORIENTED PROGRAMMING."

[22] A. S. Putra, "WORKING DIRECTORY SET FOR PARADOX 7."

[23] A. S. Putra, "ZQUERY CONNECTION

IMPLEMENTED

PROGRAMMING STUDI CASE PT. BANK BCA Tbk."

[24] A. S. Putra, D. R. Aryanti, and I. Hartati, "Metode SAW (Simple Additive Weighting) sebagai Sistem Pendukung Keputusan Guru Berprestasi (Studi Kasus: SMK Global Surya)," in Prosiding Seminar Nasional Darmajaya, 2018, vol. 1, no. 1, pp. 85-97.

[25] A. S. Putra and O. M. Febriani, "Knowledge Management Online Application in PDAM Lampung Province," in Prosiding International conference on Information Technology and Business (ICITB), 2018, pp. 181-187. 
[26] A. S. Putra, O. M. Febriani, and B. Bachry, "Implementasi Genetic Fuzzy System Untuk Mengidentifikasi Hasil Curian Kendaraan Bermotor Di Polda Lampung," SIMADA (Jurnal Sist. Inf. dan Manaj. Basis Data), vol. 1, no. 1, pp. 21-30, 2018.

[27] A. S. Putra, H. Sukri, and K. Zuhri, "Sistem Monitoring Realtime Jaringan Irigasi Desa (JIDES) Dengan Konsep Jaringan Sensor Nirkabel," IJEIS (Indonesian J. Electron. Instrum. Syst., vol. 8, no. 2, pp. 221-232.

[28] D. P. Sari, O. M. Febriani, and A. S. Putra, "Perancangan Sistem Informasi SDM Berprestasi pada SD Global Surya," in Prosiding Seminar Nasional Darmajaya, 2018, vol. 1, no. 1, pp. 289-294. 